Бережний М.О., студент, Лактіонов І.С., к.т.н., доц., доц. каф. електронної техніки, Лебедсв В.А., ас. каф. електронної техніки

ДВНЗ «Донецький національний технічний університет», м. Покровськ, Україна

\title{
ІНФОРМАЦІЙНО-ВИМІРЮВАЛЬНА СИСТЕМА МОНІТОРИНГУ Й КЕРУВАННЯ АВТОМАТИЧНИМ ПОЛИВОМ РОСЛИН У ТЕПЛИЦЯХ НА БАЗІ НЕЧІТКОЇ ЛОГІКИ
}

У статті наведено результати аналітичного огляду й критичного аналізу, а також створення інформачійно-вимірювальної системи автоматичного поливу тепличних культур із використанням теорії нечіткої логіки. Під час проведення досліджень було проаналізовано існуючі системи зрошення захищених трунтів та виявлено їх недоліки й переваги. Було розроблено алгоритм роботи створеної системи та ї̈ структурну схему. На базі пакету програмного забезпечення MATLAB \& SIMULINK та підсистеми розширення Fuzzy Logic Toolbox створено базу правил керування системою та ї̈ імітаційну модель, а також проведено іï тестування. На базі програмного забезпечення Proteus було створено комп'ютерну модель системи з еквівалентною заміною основних елементів та виконано іiі тестування з обліком реальних умов експлуатації. Встановлено, що створена система має наступні перспективи модернізаиії: бездротовий зв'язок з оператором та відображення стану системи та трунту, збереження інформаџії на хмарному сховищі, розширення функиіоналу з моніторингу та внесення інших параметрів до взаємодї у базі правил.

Ключові слова: крапельний полив, інформаційно-вимірювальна система, моніторинг, керування, нечітка логіка, вологість, температура.

Вступ. Автоматизація технологічних процесів $\epsilon$ необхідною умовою на сучасному етапі розвитку виробництва. Сільське господарство доволі сильно потребує знаходження оптимальних, універсальних і економічно обгрунтованих способів автоматичного моніторингу й керування технологічними процесами вирощування. На теперішній час існує дві найбільш розповсюджені системи поливу в тепличних умовах, а саме: дощування та крапельне зрошення. Ці системи мають різні конструкції та способи реалізації. Система крапельного поливу має такі переваги: відносно низька ціна на закупівлю необхідних витратних матеріалів; незначні витрати на електроенергію; невеликий робочий тиск, що попереджує надмірний полив грунту, вимивання грунту 3 під кореня та не пошкоджує листя через попадання води на нього; надходження води здійснюється біля кореня рослини, що сприяє точному потраплянню вологи в необхідному для певних типів і періодів вегетації рослин об'ємі.

На сьогодні існуе доволі багато науково-технічних рішень із побудови систем автоматичного та автоматизованого крапельного поливу, проте вони відрізняються технологіями керування поливом, наявністю або відсутністю підсистем моніторингу поточного стану рослин та можливістю дистанційного вимірювального контролю [1-4]. Попри це, у результаті проведеного аналізу існуючих систем, встановлено, що більшість із них працюють на базі двохпозиційних алгоритмів. Основою роботи таких систем є мікроконтролер, який залежно від отриманої інформації з датчиків вмикає / вимикає подачу води 3 насосу або вмикається залежно від стану вбудованого таймера. Звертаючи увагу на недоліки існуючих систем, виникає необхідність в удосконаленні системи шляхом обліку співвідношення основних факторів, що впливають на вологість грунту, та в залежності від цього керувати потужністю насосу в автоматичному режимі. Таким чином, науково-технічна задача удосконалення існуючих систем автоматичного поливу тепличних культур за рахунок створення й впровадження адаптивних алгоритмів моніторингу й керування $\epsilon$ актуальною.

Мета та об'єкт дослідження. Основна мета роботи полягає в удосконаленні технологічних режимів вирощування тепличних культур шляхом розробки інформаційновимірювальної системи моніторингу й керування автоматичним поливом рослин у теплицях на базі нечіткої логіки. Об'єкт дослідження - нестаціонарні процеси автоматичного моніторингу й керування параметрами крапельного поливу тепличних культур.

Базова структура та алгоритм функціонування системи. Система автоматичного поливу створена на базі теорії нечіткої логіки, яка дає змогу розробити систему множин

(C) Бережний М.О., Лактіонов І.С., Лебедєв В.А. 
варіантів керування системою. Вона складається з блоків вхідних сигналів, бази правил керування та блоку вихідного сигналу. За допомогою пакету програмного забезпечення MATLAB \& SIMULINK та підпрограми розширення Fuzzy Logic Toolbox створено автоматичну та повністю автономну систему керування поливом грунту. Ця система залежить від двох вхідних параметрів, що поділені на п'ять рівнів трикутних та трапецеїдальних вхідних функцій вологості та температури грунту, а також п'ять рівнів вихідних функцій ШІМкерування насосом, що подає воду до систему поливу. Рівні поділяються згідно з актуальними державними нормами вирощування сільськогосподарських культур у теплицях $[5,6]$.

Блок вхідних даних поділяться на дві частини:

- вхідні дані з виходу сенсора температури в діапазоні від 10 до $30^{\circ} \mathrm{C}$;

- вхідні дані з виходу сенсора вологості в діапазоні від 50 до $95 \%$.

Поділ вищевказаних діапазонів вимірювання фізичних параметрів на відповідні піддіапазони наведено в таблиці 1. Результати налаштування параметрів блоків вхідних даних для сенсорів температури й вологості наведено на рис. 1 і 2, відповідно.

Таблиця 1

Піддіапазони вхідних сигналів

\begin{tabular}{cccccc}
\hline Параметр & Minimum & $\begin{array}{c}\text { Less than } \\
\text { normal }\end{array}$ & Normal & $\begin{array}{c}\text { More than } \\
\text { normal }\end{array}$ \\
\hline $\begin{array}{c}\text { Температура } \\
\left(T_{\text {soil }}{ }^{\circ} \mathrm{C}\right)\end{array}$ & $10-14$ & $12-19$ & $17-24$ & $22-28$ \\
\hline $\begin{array}{c}\text { Bологість } \\
\left(H_{\text {soil }} \%\right)\end{array}$ & $50-58$ & $55-68$ & $65-80$ & $77-90$ \\
\hline
\end{tabular}

Рис. 1. Блок вхідних даних для датчика температури

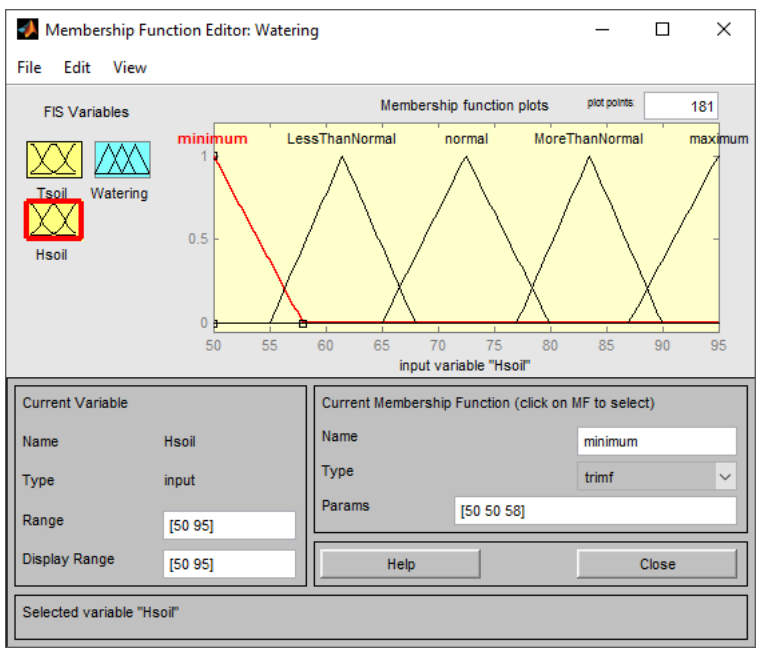

Рис. 2. Блок вхідних даних для датчика вологості

(C) Бережний М.О., Лактіонов I.С., Лебедєв В.А. 
На рис. 1 введено наступні позначення: 1 - кнопка за допомогою якої обирається вікно налаштування вхідного сигналу 3 датчика температури; 2 - діапазон можливих вхідних сигналів; 3 - вікно відображення створених рівнів за якими буде реалізовуватись розподілення за значеннями сигналу; 4 - вікно перейменування функції рівня; 5 - кнопка для вибору типу функції рівня; 6 - вікно діапазону рівня функції.

Блок вихідних даних складається з однієї частини. В ньому задаються функції керування вихідним сигналом, а саме діючим значенням напруги вихідного сигналу на базі широтноімпульсної модуляції. За допомогою зміни напруги змінюється інтенсивність роботи насосу поливу грунту у теплиці. Напруга змінюється в діапазоні від 0 до 5 В. У самому діапазоні, як і в блоці вхідних даних є п'ять рівнів, як показано в таблиці 2.

Таблиця 2

Рівні вихідного сигналу

\begin{tabular}{cccccc}
\hline Рівень & Off & Low & Medium & Fast & Intensely \\
\hline Інтенсивність & $0-1$ & $0,75-2$ & $\begin{array}{c}1,75- \\
3,25\end{array}$ & $3-4,25$ & $4-5$ \\
роботи & $0-1$ & & & \\
\hline
\end{tabular}

Для більш плавного переключення між рівнями використовується накладання крайніх значень відрізків, як показано на рис. 3.

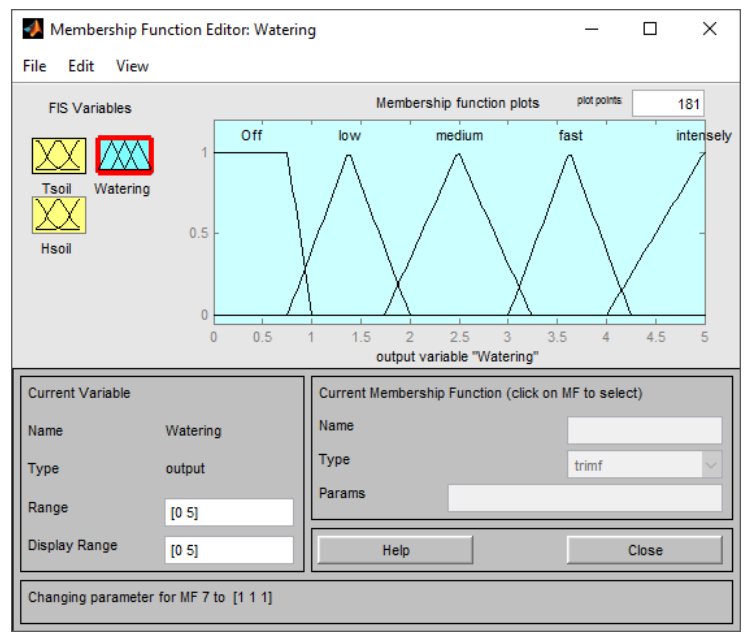

Рис. 3. Блок вихідного сигналу для керуванням насосом

Основним виконуючим блоком даної системи є блок бази правил. За його допомогою створено сукупність функцій залежності вихідного сигналу від вхідних сигналів. У залежності від миттєвих значень вхідних сигналів у редакторі правил (див. рис. 4) обирається відповідне рівняння функції керування. Для підвищення ергономічності уявлення принципів роботи системи керування наведено матрицю відповідності правил до функцій належності параметрів, як показано в таблиці 3.

Таблиця 3

Матриця відповідності правил до функцій належності параметрів

\begin{tabular}{|c|c|c|c|c|c|}
\hline$W_{\text {soil }} \%$ & $10-14$ & $12-19$ & $17-24$ & $22-28$ & $26-30$ \\
\hline $50-58$ & fast & intensely & intensely & intensely & intensely \\
\hline $55-68$ & medium & fast & fast & fast & intensely \\
\hline $65-80$ & OFF & $O F F$ & $O F F$ & $O F F$ & low \\
\hline $77-90$ & OFF & $O F F$ & $O F F$ & $O F F$ & low \\
\hline $87-95$ & $O F F$ & $O F F$ & $O F F$ & $O F F$ & low \\
\hline
\end{tabular}

(C) Бережний М.О., Лактіонов І.С., Лебедєв В.А. 


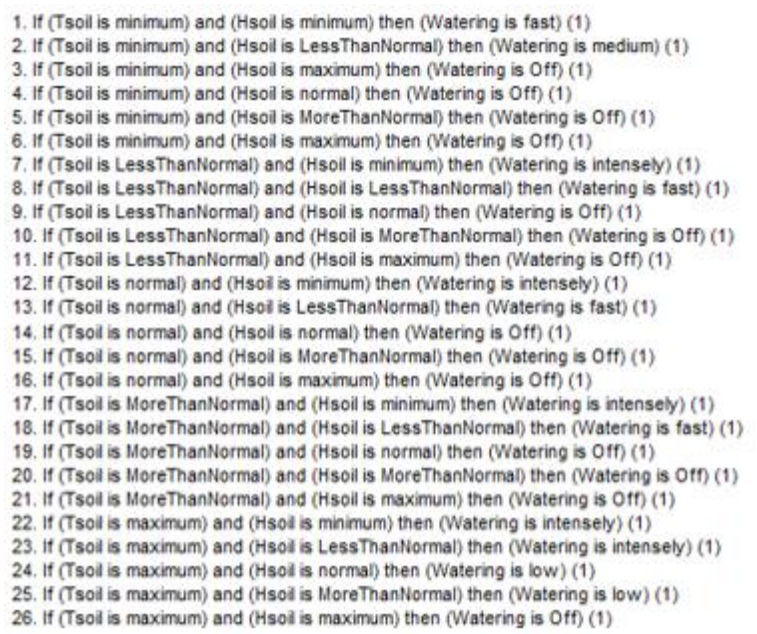

Рис. 4. Синтезована база правил обробки вхідних сигналів

3 метою тестування та оцінки адекватності функціонування розроблюваної системи авторами статті було створено імітаційну модель у ППП MATLAB \& SIMULINK, як показано на рис. 5. В якості вхідних сигналів було використано генератори випадкового сигналу, амплітуда яких відповідає діапазону температур та відносної вологості на відповідних сенсорах. Для більшого наближення отриманих результатів моделювання до реальних умов до кожного із сигналів додатково додано генератор шуму, сигнал якого відповідає допустимій випадковій похибці вимірювання відповідних фізичних параметрів. Вхідні сигнали надходять до мікроконтролера зі встановленим програмним забезпеченням нечіткої логіки. Сигнали оброблюються та мікроконтролер генерує відповідний вихідний ШІМ-сигнал $[7,8]$.

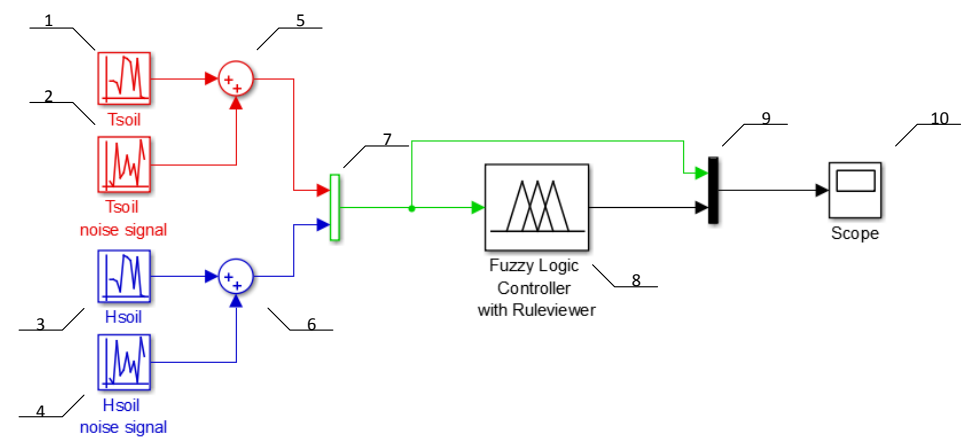

Рис. 5. Імітаційна модель системи керування крапельним зрошенням

На рис. 5 введено наступні позначення: 1, 3-генератори випадкового сигналу; 2, 4 генератори шуму; 5, 6 - суматори сигналів; 7 - мультиплексор вхідних сигналів; 8 - контролер нечіткої логіки; 9 - мультиплексор вхідних і вихідного сигналу; 10 - осцилограф.

Результати імітаційного тестування розробленої моделі системи наведено на рис. 6. і 7.

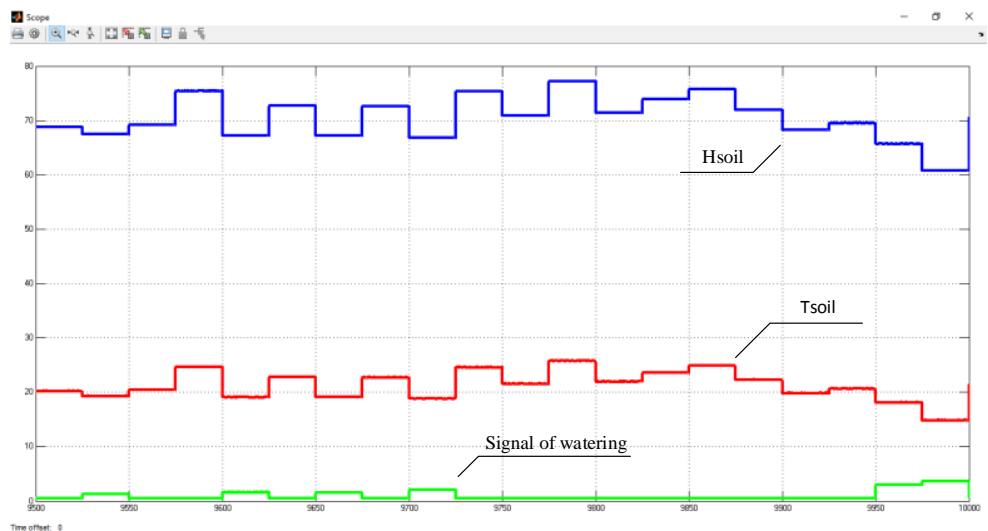

Рис. 6. Динаміка вхідних і вихідного сигналів розробленої системи

(C) Бережний М.О., Лактіонов І.С., Лебедсв В.А. 


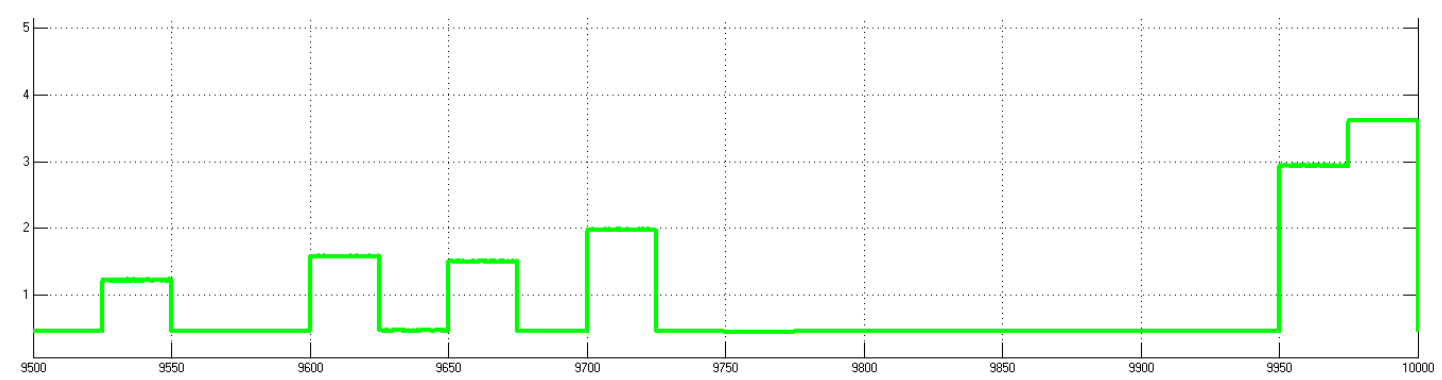

Рис. 7. Фрагмент осцилограми вихідного сигналу системи

Результати комп'ютерного тестування. Задля тестування розробленої моделі з обліком реальних умов експлуатації було використано принцип імітаційного моделювання в середовищі Proteus. Базове апаратне забезпечення, яке використано під час побудови моделі, наведено в таблиці 4. Результати розробки та тестування моделі системи наведено на рис. 8 i 9.

Таблиця 4

Елементи моделі системи керування автоматичним поливом

\begin{tabular}{|c|c|c|}
\hline \multicolumn{2}{|c|}{ Складовий елемент системи } & \multirow{2}{*}{ Функції та призначення } \\
\hline Фізичний рівень & Імітаційний рівень & \\
\hline Arduino UNO & Arduino UNO & $\begin{array}{ll}\text { база для } & \text { підключення } \\
\text { датчиків, } & \text { додаткового } \\
\text { облаштування та опрацювання } \\
\text { вхідної і вихідної інформації }\end{array}$ \\
\hline $\begin{array}{c}\text { датчик вологості } \\
\text { DFRobot }\end{array}$ & потенціометр & $\begin{array}{lr}\text { зчитування } & \text { відносної } \\
\text { вологості } \quad \text { в } & \text { грунті } \\
\text { діелькометричним методом та } \\
\text { передача контролеру }\end{array}$ \\
\hline $\begin{array}{c}\text { датчик температури } \\
\text { DS18B20 } \\
\end{array}$ & потенціометр & $\begin{array}{lr}\text { зчитування } & \text { температури } \\
\text { грунту та передача контролеру }\end{array}$ \\
\hline мембранний насос & DC-мотор & $\begin{array}{l}\text { підкачка води в систему } 3 \\
\text { потужністю, яка залежить від } \\
\text { вихідного сигналу }\end{array}$ \\
\hline осцилограф & $\begin{array}{l}\text { осцилограф та } \\
\text { СОМ-порт }\end{array}$ & $\begin{array}{l}\text { візуалізація вхідних сигналів } 3 \\
\text { датчиків та вихідного сигналу } \\
\text { керування насосом }\end{array}$ \\
\hline
\end{tabular}

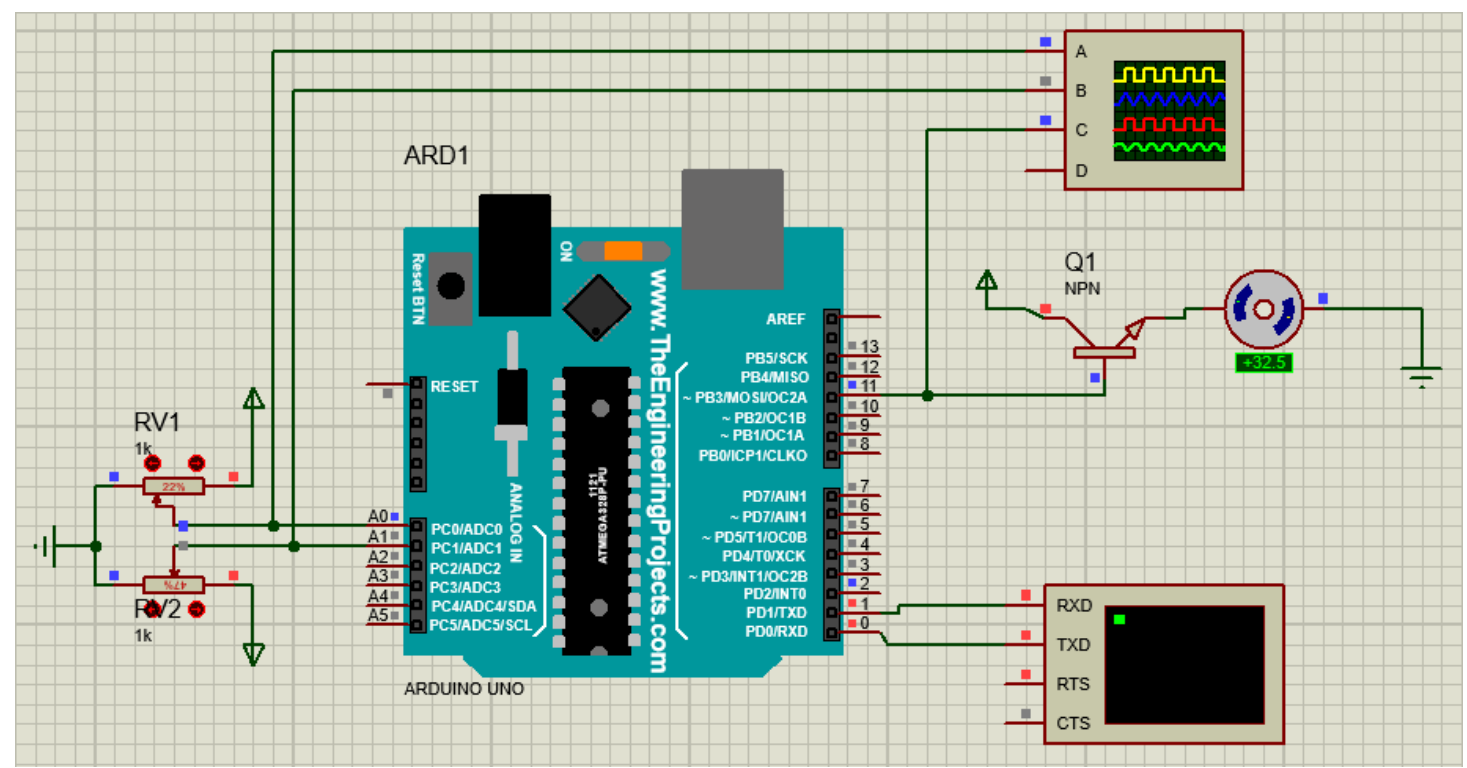

Рис. 8. Загальна структура системи в програмі Proteus

(C) Бережний М.О., Лактіонов I.С., Лебедєв В.А. 


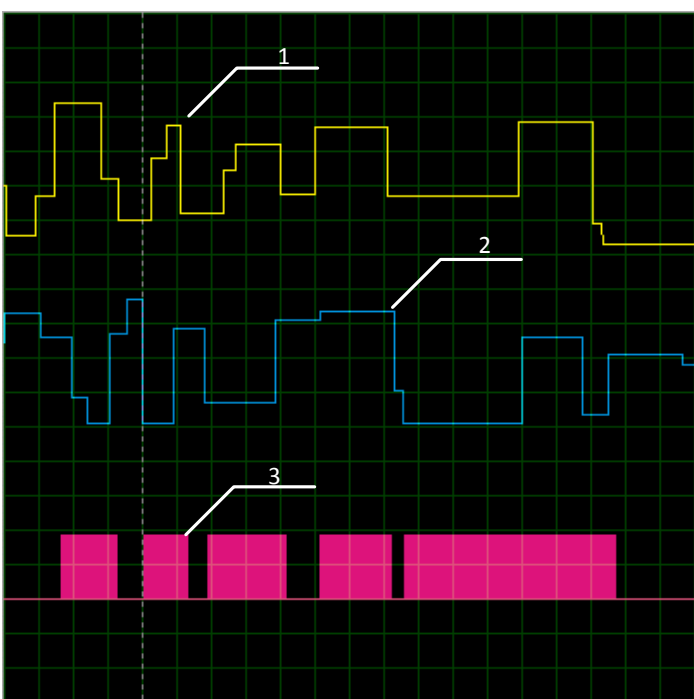

a)

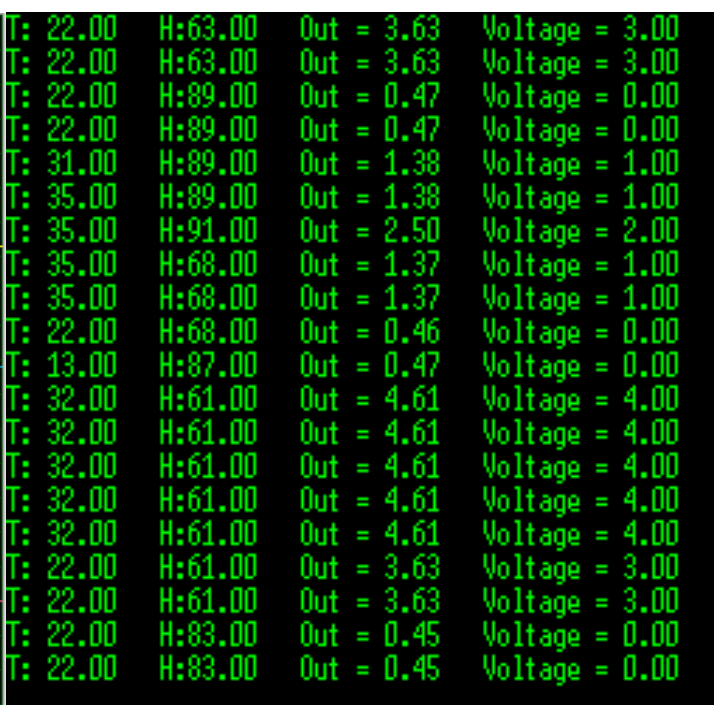

б)

Рис. 9. Осцилограма (а) та результати зчитування інформації з послідовного порту (б)

На рис. 9 введено наступні позначення: 1 - сигнал 3 сенсора температури, 2 - сигнал 3 сенсора вологості, 3 - ШІМ-сигнал керування насосом.

На підставі аналізу отриманих результатів моделювання встановлено, що синтезована модель відпрацьовує розроблені алгоритми функціонування та може бути використана в якості базової під час розробки й проектування макетного зразка системи.

Перспективні шляхи подальших досліджень системи. Основний перелік облаштування не передбачає відображення та запис інформації для оператора, а тим паче можливість віддалено впливати на систему. Для цього запропоновано можливий варіант розширення функціоналу системи. Розширення стає можливим за допомогою переліку додаткового облаштування. В цей перелік входять: модуль годинника реального часу DS3231 [9]; модуль додаткової обробки й передачі інформації NodeMCU на базі ESP8266 [10].

Платформа на основі ESP8266 призначена для створення різних пристроїв інтернету речей (IoT). Модуль призначено для відправки й отримання інформації в локальній або глобальній мережі за Wi-Fi технологією. В даному випадку цей модуль необхідний для:

- передачі інформацію з датчиків на онлайн платформу ThingSpeak;

- організації передачі даних оператору на android-додаток Blynk [11];

- керування системою поливу через Blynk-додаток.

За допомогою цього додатку існує можливість створити підсистему онлайн відстеження поточного стану системи, стану грунту та віддаленого керування системою. Запропоновану структурну й функціональну схеми подальших досліджень системи наведено на рис. 10 i 11.

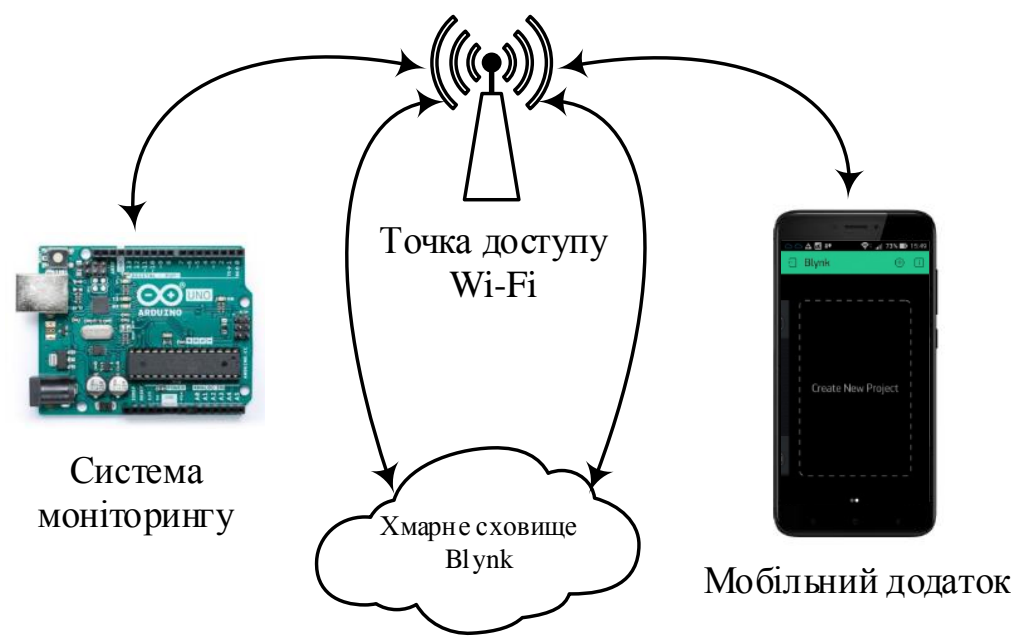

Рис. 10. Структурна схема зв'язку системи моніторингу та мобільного додатку 


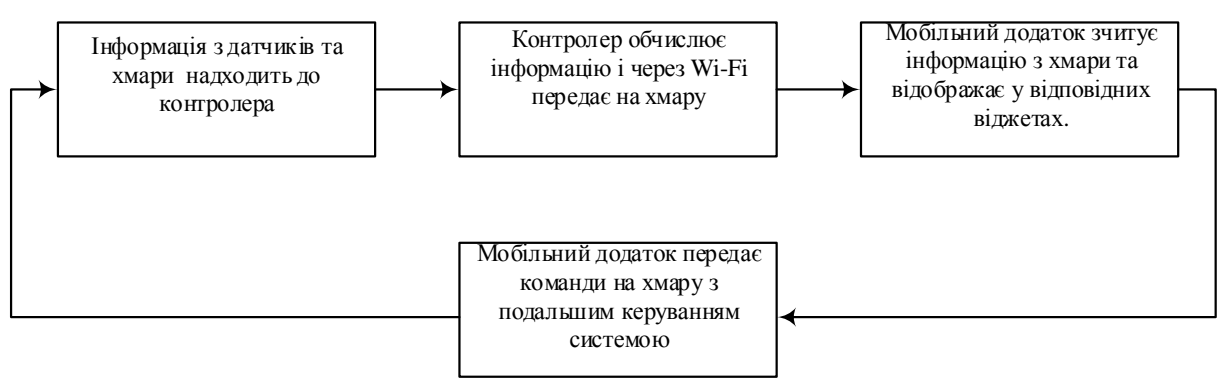

Рис. 11. Алгоритм роботи взаємодії системи з платформою Blynk

Отже, запропоновані перспективні шляхи удосконалення системи моніторингу й керування технологічним процесом крапельного зрошення тепличних грунтів дозволять обгрунтувати рекомендації з впровадження розробленого вимірювача до реальних умов.

Висновки. Під час проведення досліджень 3 удосконалення технологічних режимів вирощування тепличних культур шляхом розробки інформаційно-вимірювальної системи моніторингу й керування автоматичним поливом рослин у теплицях на базі нечіткої логіки було отримано наступні основні результати:

- встановлено основні недоліки існуючих систем автоматичного керування технологічним процесом крапельного зрошення тепличних грунтів, які обмежують їх впровадження до реальних умов експлуатації;

- розроблено сукупність логічних правил, яка базується на результатах вимірювального моніторингу вологості та температури тепличних грунтів 3 обліком актуальних вимог до технологічних процесів вирощування культур в умовах захищеного грунту;

- протестовано створену імітаційну модель системи, що довело первинну можливість іiі використання під час розробки експериментального зразка вимірювача;

- обгрунтовано перспективні напрямки подальших досліджень системи задля розширення іiі функціональних можливостей.

\section{Інформаційні джерела}

1. Обладнання для крапельного зрошення. [Електронний ресурс]: Контролер автополиву ELC-401i-e Hunter. - Режим доступу: https://agras.com.ua/p553610663-kontroller-avtopolivaelc.html. - Назва $з$ титул. екрана.

2. ТМ "Рідна Роса". [Електронний ресурс]: Крапельний полив в теплиці. - Режим доступу: https://gtconcept.com.ua/greenhouses/oborudovanie-teplic/poliv-teplicy.html. - Назва 3 титул. екрана.

3. Izzuddin, T.A. Smart irrigation using fuzzy logic method / T.A. Izzuddin, M.A. Johari, M.Z.A. Rashid, M.H. Jali // ARPN Journal of Engineering and Applied Sciences. - Islamabad, 2018. Vol. 13 (2). - P. $517-522$.

4. Ceballos, M. Fuzzy System of Irrigation to Applied to the Growth of Habanero Pepper (Capsicum chinese Jacq.) under Protected Conditions in Yucatan - Mexico / M. Ceballos, J.L. Gorricho, O. Palma, M. Huerta, D. Rivas, M. Erazo // International Journal of Distributed Sensor Networks. - Geneva, 2015. - Vol. 11 (6). - P. 1 - 17.

5. ВНТП АПК-19-07. Тепличні і оранжерейні підприємства. Споруди захищеного грунту для фермерських (селянських) господарств: Відомчі норми технологічного проектування / М-во аграр. політ. України. - К.: «ХІК», 2007. - 140 с.

6. Both, A.J. Guidelines for measuring and reporting environmental parameters for experiments in greenhouses / A.J. Both, L. Benjamin, J. Franklin et al. // Plant Methods. - Melbourne, 2015. Vol. 11 (43). - P. $1-18$.

7. Лактіонов, І.С. Комп'ютеризована система комплексного моніторингу й керування мікрокліматом промислових теплиць на базі нечіткої логіки / І.С. Лактіонов, О.В. Вовна, М.О. Бережний, В.А. Лебедєв // Вісник КрНУ імені Михайла Остроградського. - Кременчук, 2019. - № 3 (116). - C. 120-129.

8. Вовна, О.В. Комп'ютеризована технологія моніторингу й керування системою автоматичного поливу рослин у теплицях на базі нечіткої логіки / О.В. Вовна, І.С. Лактіонов, М.О. Бережний, В.А. Лебедєв // Перспективні напрямки сучасної електроніки, інформаційних і 
комп’ютерних систем: тези доповідей на Всеукр. наук.-практ. конф. MEICS-2019. - К. : м. Дніпро 2019 - С. 77 - 78.

9. Arduino модулі [Електронний ресурс]: Годинник реального часу. - Режим доступу: https://3d-diy.ru/wiki/arduino-moduli/chasy-realnogo-vremeni-ds3231/. - Назва з титул. екрана.

10. Arduino Master [Електронний pecypc]: ESP8266 Node MCU. - Режим доступу: https://arduinomaster.ru/platy-arduino/esp8266-nodemcu-v3-lua. - Назва з титул. екрана.

11. Офіційний сайт додатку Blynk [Електронний ресурс]: Blynk.io. - Режим доступу: https://blynk.io/. - Назва з титул. екрана.

Бережной М.О., студент, Лактионов И.С., к.т.н., доц., доц. каф. электронной техники, Лебедев В.А., асс. каф. электронной техники

ГВУЗ «Донецкий национальный технический университет», г. Покровск, Украина

\section{ИНФОРМАЦИОННО-ИЗМЕРИТЕЛЬНАЯ СИСТЕМА МОНИТОРИНГА И УПРАВЛЕНИЯ АВТОМАТИЧЕСКИМ ПОЛИВ РАСТЕНИЙ В ТЕПЛИЦАХ НА БАЗЕ НЕЧЕТКОЙ ЛОГИКИ}

В статье приведены результаты аналитического обзора и критического анализа, а также создания информационно-измерительной системы автоматического полива тепличных культур c использованием теории нечеткой логики. При проведении исследований были проанализированы существующие системы орошения защищенных почв и выявлены их недостатки и преимущества. Был разработан алгоритм работы созданной системы и ее структурная схема. На базе программного пакета MATLAB \& SIMULINK и подсистемы расширения Fuzzy Logic Toolbox создана база правил управления системой и ее имитационная модель, а также проведено ее тестирование. На базе программного обеспечения Proteus была создана компьютерная модель системы с эквивалентной заменой основных элементов и выполнено ее тестирование с учетом реальных условий эксплуатации. Установлено, что созданная система имеет следующие перспективы модернизации: беспроводная связь с оператором и отображения состояния системы и почвы, сохранение информации на облачном хранилище, расширение функционала мониторинга и внесение ряда информативных параметров к взаимодействию в базе правил.

Ключевые слова: капельный полив, информационно-измерительная система, мониторинг, управление, нечеткая логика, влажность, температура.

\section{Berezhnyi, I. Laktionov, Ph.D., V. Lebediev}

SHEI 'Donetsk National Technical University', Pokrovsk, Ukraine

\section{INFORMATION-MEASURING SYSTEM OF MONITORING AND CONTROL OF THE GREENHOUSES PLANTS AUTOMATIC IRRIGATION BASED ON FUZZY LOGIC}

The results of an analytical review and critical analysis, as well as the creation of the information-measuring system of monitoring and control of the greenhouses plants automatic irrigation based on fuzzy logic have been described in the article. During the research, the existing irrigation systems of protected soils have been analyzed and their disadvantages and advantages have been identified. The algorithms of the created system and its block diagram have been developed. The system control rule base has been created on the basis of the MATLAB \& SIMULINK software package and Fuzzy Logic Toolbox extension subsystem. A simulation model of the software component has been designed and tested. A computer model of the system with an equivalent replacement of the main elements has created on the basis of Proteus software. The system has been tested taking into account actual operating conditions. Promising areas for further research have been established, namely: wireless communication with the operator and displaying the state of the system and soil, saving information on a cloud storage, expanding the monitoring functionality and introducing a number of informative parameters for interaction in the rule base.

Keywords: drip irrigation, information-measuring system, monitoring, control, fuzzy logic, humidity, temperature. 